\title{
CD33 wt Allele
}

National Cancer Institute

\section{Source}

National Cancer Institute. CD33 wt Allele. NCI Thesaurus. Code 697245.

Human CD33 wild-type allele is located in the vicinity of $19 q 13.3$ and is approximately 15 $\mathrm{kb}$ in length. This allele, which encodes myeloid cell surface antigen CD33 protein, plays a role in the regulation of both cell-cell signaling and cell adhesion. 